Tyndale Bulletin 65.2 (2014) 219-245

\title{
THE LETTERS OF CLAUDIUS TERENTIANUS AND THE NEW TESTAMENT \\ INSIGHTS AND OBSERVATIONS ON EPISTOLARY THEMES ${ }^{1}$
}

\author{
Peter M. Head \\ (pmh15@cam.ac.uk)
}

\begin{abstract}
Summary
Eleven papyrus letters from the early second century (P. Mich. 467-480 \& inv. 5395) are studied in relation to parallel interests expressed within NT letters, on the topics of physical layout and formatting, discussions of health, the desire for news and the role of greetings, the role of the letter carrier and the use of letters of recommendation.
\end{abstract}

\section{Introduction}

This article compares eleven papyrus letters written early in the Second Century by Claudius Terentianus to his father Claudius Tiberianus with the letters of the New Testament. For more than a century, since the early publications of documentary papyri from Egypt, New Testament scholars have had access to thousands of real letters in koine Greek. Knowledge gained from the study of these letters has impacted New Testament studies in many and various ways. ${ }^{2}$ But it is difficult to

\footnotetext{
1 Early versions of this paper were presented to the Papyrology and Early Christianity Group at the SBL Annual Meeting in San Francisco (November 2011) and at the Conference on Papyrology and Early Christianity/Biblical Studies in Cambridge (November 2012).

2 Among a wealth of literature the following may be particularly recommended: S. K. Stowers, Letter Writing in Greco-Roman Antiquity (LEC 5; Philadelphia: Westminster, 1986); H.-J. Klauck (with D. P. Bailey), Ancient Letters and the New Testament: A Guide to Context and Exegesis (Waco, TX: Baylor UP, 2006). For comparative material we shall refer especially to the following collections and studies: F. X. J. Exler, The Form of the Ancient Greek Letter: A Study in Greek Epistolography (Washington DC: Catholic University of America, 1923); H. Koskenniemi, Studien zur Idee und Phraseologie des griechischen Briefes bis 400 n. Chr. (Annales Academiae
} 
study thousands of texts, and if one does so, it will be at a significant level of generalisation and abstraction away from the particularity of the correspondence. So in this paper I will investigate one small slice of the thousands of papyrus letters, a collection of eleven letters found in a larger archive (including other letters to the same addressee), under the stairs in a particular house in Karanis.

This small collection was chosen primarily because the letters themselves, as we shall see, reflect a wide-ranging acquaintance with and interest in a variety of aspects of epistolary communication. ${ }^{3}$ In addition they are somewhat distinctive in relation to the bulk of documentary letters on papyrus in that: a) they have a specific provenance: this group of letters was found, as part of a larger archive of letters, in the archaeological context of a domestic building in Karanis; b) they are bilingual, at least in the sense that some of the letters were written in Latin and some in Greek; ${ }^{4}$ c) some at least of them, were written by Claudius Terentianus while he was in service in the Roman navy outside of Egypt. This article thus serves as a more wide-ranging supplement to my earlier discussion of letter carriers in the documentary papyri from Oxyrhynchus. ${ }^{5}$

In what follows I will attempt a series of 'compare and contrasts' between the letters of Claudius Terentianus and the letters of the New Testament, which will illuminate our understanding of several different facets of epistolary communication. In a moment I shall introduce both sender and receiver; then in the next section I will briefly introduce the town of Karanis, the excavation of the town and of this house $(\mathrm{C} / \mathrm{B}$

Scientiarum Fennicae, Ser. B, tom. 102. 2; Helsinki: Suomalainen Tiedeakatemia, 1956); J. L. White, 'Epistolary Formulas and Cliches in Greek Papyrus Letters' SBL 1978 Seminar Papers 2 (1978): 289-319; J. L. White, Light from Ancient Letters (Foundations \& Facets; Philadelphia: Fortress, 1986).

3 In P. Mich 469: the father, Claudius Tiberianus is described as a speculator-'these scouts formed a special division in each legion ... under the emperors they were employed as special adjutants, messengers, and body-guards of a general' (OLD) - so he may have been professionally connected with the transmission of the military post.

4 In terms of epistolary forms and standard expressions the Latin letters (P. Mich. 467-72, see the list below) show extensive Greek influence (including broadly conforming to formulas and expressions common in Greek letter-writing). These letters are relevant to questions of bilingualism and the type of colloquial Latin used in veteran circles which we shall not be dealing with here, cf. further J. N. Adams, The Vulgar Latin of the Letters of Claudius Terentianus (P. Mich. VIII, 467-472) (Manchester: MUP, 1977); C. Lehmann, 'On the Latin of Claudius Terentianus (P. Mich. VIII, 467-72)’ Cuadernos de Filología Clásica XXI (1988): 11-23.

5 P. M. Head, 'Named Letter-Carriers among the Oxyrhynchus Papyri' JSNT 31 (2009): 279-99. 
167) in particular. Then we will focus on the papyri themselves, especially their physical features. In the following section I will discuss ways in which these letters reflect themes that are common to the letters of Graeco-Roman antiquity, and their relevance to the study of the letters of the New Testament under the heading topics of health, making connections, the role of the letter carrier and the use of letters of recommendation.

The letters of Claudius Terentianus are not dated, so a strictly chronological arrangement is not possible, nor does he regularly specify his current location. Notwithstanding these difficulties it would appear that Claudius Terentianus was enlisted in the Roman navy, based in Alexandria (P. Mich. 467), but from there at one point was sent to Syria (P. Mich. 467:8), later lying ill on a ship (P. Mich. 468:13), planning a trip to Alexandria (P. Mich. 471), and waiting in Alexandria (P. Mich. 477:14f). In P. Mich. 468:37 he expresses a desire to be transferred to the army to join a cohort (i.e. become a legionary), and in P. Mich. 476 he identifies himself as a legionary soldier (P. Mich. 476 verso: $\lambda \varepsilon[\gamma(\tilde{\omega} v o \zeta] \sigma \tau \rho \alpha[\tau \imath \omega ́ \tau o v]){ }^{6}$

All of these letters were sent from Claudius Terentianus to his 'father' Claudius Tiberianus in Karanis. Interestingly, it is not entirely clear whether Claudius Tiberianus was the 'real' father of Claudius Terentianus, although this is the customary form of address which Claudius Terentianus uses_-'father' (so P. Mich. 467:1; 468:1f \& verso; 469:2; 471 verso; 476:1; 477:2; 478.[2]; 479:2; 480:1; and for 'son' cf. P. Mich. 468 verso; 476 verso); and in addition Claudius Tiberianus in a letter to a third party says 'Claudius my son sends many salutations to you' (P. Mich. 472:23-24), while a letter to Claudius Tiberianus from an unknown sender (perhaps his sister Tabatheus) includes the comment that 'I received a letter from Claudius your son' (P. Mich. 474:12). The main complication is that Claudius Terentianus also refers to another person as 'Ptolemaeus my father' (P. Mich. $467: 32 ; 471: 21)$. The complexity for us as readers is exemplified in P. Mich 468, a letter addressed to 'Claudius Tiberianus, his father' which

6 On the dating of the letters the occupation level was dated archaeologically to AD 80-180, which fits the internal indications of the letters that are normally dated to early in the Second Century, see H. C. Youtie and J. G. Winter, Papyri and Ostraca from Karanis, Second Series (Michigan Papyri, Vol. VIII) (University of Michigan Studies, Humanistic Series 50; Ann Arbor: University of Michigan Press, 1951), 16-74; S. Strassi, L'archivio di Claudius Tiberianus da Karanis (APF 26; Berlin/New York: Walter de Gruyter, 2008), 4. 
later states, 'my mother and father and brothers greet you' (P. Mich. 468:46f.). Here we have an illustration of the way in which kinship terms were used in extended, or fictive, ways in the documentary papyri. ${ }^{7}$ The original editors took the similarity of names and the intimate character of the correspondence as support for the view that Claudius Tiberianus and Claudius Terentianus 'are in reality father and son', and that 'father' was applied to Ptolemaeus as a loose term of respect, a view that we shall also adopt in what follows. ${ }^{8}$

\section{Karanis}

Karanis was a Graeco-Roman town in the north east of the Fayyum with a population of perhaps around 3, 300 in the early part of the Second Century (when our letters were written). ${ }^{9}$ Grenfell and Hunt, who later made their name through their papyrological discoveries in Oxyrhynchus, came to Karanis in 1895 and made some initial excavations and mapped the town, but left for the 'greener' pastures of Oxyrhynchus in 1897. From 1924 Francis Kelsey, from the University of Michigan, led eleven seasons of excavations which resulted in a large number of papyri and a thorough mapping of the whole city and its houses (and the recovery of around 44, 000 artifacts and hundreds of texts on papyrus). ${ }^{10}$ In one of the hundreds of houses which were excavated (designated C/B 167), a collection of twenty-four papyrus texts was 'discovered under a stairway in a house on the second level

7 E. Dickey, 'Literal and Extended Use of Kinship Terms in Documentary Papyri', Mnemosyne 57 (2004): 131-76.

8 Youtie and Winter, Papyri and Ostraca from Karanis, 17; supported by Dickey, 'Literal and Extended', 139-40. Recently, Strassi has argued for the alternative view, i.e. Ptolemaeus as Claudius Terentianus' 'true' father, and Claudius Tiberianus addressed as 'father' as a fictive honorific, L'archivio di Claudius Tiberianus, 109125 .

9 A. E. B. Boak and E. E. Peterson, Karanis: Topographical and Architectural Report of Excavations During the Seasons 1924-28 (University of Michigan Humanistic Series 25; Ann Arbor: University of Michigan Press, 1931).

10 E. K. Gazda, ed. Karanis: An Egyptian Town in Roman Times: Discoveries of the University of Michigan Expedition to Egypt (1924-1935) (2nd edition with preface and bibliography by T. G. Wilfong; KMP 1; Ann Arbor: Kelsey Museum of Archaeology, The University of Michigan, 2004); J. G. Pedley, The Life and Work of Francis Willey Kelsey: Archaeology, Antiquity, and the Arts (Ann Arbor: University of Michigan Press, 2012). 
from the top of the mound.'11 Other documents and artifacts were found in the same house, including seven papyri found in other rooms (one of which is a text of Thucydides), four ostraka, and a range of high quality glass objects, suggesting that the residents of the house were relatively well to do and literate. ${ }^{12}$

In the town itself literary papyri were found in 11 of the 197 houses $(5: 6 \%)$ and private letters in 13 houses $(6: 6 \%){ }^{13}$ Tax documents reveal that $14 \%$ of the population had Latin names, a feature commensurate with the contents of the letters which suggest a high level of veteran settlement. ${ }^{14}$ Notwithstanding the presence of Roman settlers, $98 \%$ of the papyri found at Karanis are Greek. ${ }^{15}$ There is no evidence of any Christian presence in Karanis in the early part of the Second Century. ${ }^{16}$

In this article we are focusing on a narrow slice of the papyrological finds from Karanis, and we begin with the physical format of the letters.

11 H. C. Youtie and J. G. Winter, Papyri and Ostraca from Karanis, Second Series (Michigan Papyri, Vol. VIII) (University of Michigan Studies, Humanistic Series 50; Ann Arbor: University of Michigan Press, 1951), 16. These are P. Mich. Inv. 53895412 - the fullest of which were published as P. Mich. 467-81. The letters of Claudius Terentianus to Claudius Tiberianus are P. Mich. VIII.467-71 (in Latin) and 476-80 (in Greek). The other letters are also family-related: P. Mich. 473 and 474 (possibly) are by his sister Tabatheus to Claudius Tiberianus; P. Mich. 475 is by Papirius Apollinarius to his brother Claudius Tiberianus. P. Mich. 481 is also by Terentianus, a letter to his sister.

12 The seven other texts are designated as P. Mich. Inv. 5386, 5387, 5388, 5413 [Thucydides, Histories, book 2.62.5f], 5414, 5415, 5417. For an integrative approach to the texts, artefacts and archaeological study of this house see R. P. Stephan and A. Verhoogt, 'Text and Context in the Archive of Tiberianus (Karanis, Egypt; 2nd Century AD)' BASP 42 (2005): 189-201.

13 R. P. Stephan, 'Texts and Artifacts: A Spatial Analysis of Papyri at Karanis', Past Imperfect 16 (2010): 92-131. Stephan suggests that this provides the best correspondence to literacy (p.112), on this cf. also G. W. Schwendner, 'Literature and Literacy at Roman Karanis: Maps of Reading' Proceedings of the 24th International Congress of Papyrology Helsinki, 1-7 August, 2004 (Comm. Hum. Litt. 122; Helsinki: Societas Scientiarum Fennica), 991-1006.

14 R. Alston, Soldier and Society in Roman Egypt: A Social History (London: Routledge, 1998), 117-42 has an interesting discussion of Karanis and the veterans and army officers attested there (including a brief discussion of the career of Claudius Terentianus, pp. 135-37), see p. 121 for the tax documents (P. Ryl. 594 from AD 145146 and P. Mich. 224 from AD 172-173).

15 Stephan, 'Texts and Artifacts', 108; for public inscriptions in Greek see Gazda, Karanis, 33.

16 For later evidence, including a portion from a third century Christian psalter, see G. S. Schwendner, 'A Fragmentary Psalter from Karanis and its Context', Jewish and Christian Scripture as Artifact and Canon (eds. C. A. Evans and H. D. Zacharias; SSEJC 13; LNTS 70; London: T \& T Clark / Continuum, 2009), 117-36. 


\section{Physical Features of the Letters}

We can begin with the apparently simple procedure of collecting and interpreting the physical features of the letters. ${ }^{17}$

\begin{tabular}{|c|c|c|c|c|c|}
\hline P. Mich. & APIS & Language & $\begin{array}{l}\text { Size } \\
h \times w\end{array}$ & $\begin{array}{l}\text { Margins } \\
\text { (approx. cm) }\end{array}$ & Address \\
\hline $\begin{array}{l}467= \\
\text { Inv. } 5391\end{array}$ & 2445 & Latin & $23 \times 22$ & $\begin{array}{l}\text { Left; } 1.5-2.5 \text { (with } \\
\text { additional writing); } \\
\text { right: } 0-1 \text {; top: } 1\end{array}$ & Traces \\
\hline $\begin{array}{l}468= \\
\text { Inv. } 5390\end{array}$ & 2444 & Latin & $21.8 \times 26.5$ & $\begin{array}{l}\text { Left: } 1.5-2 \text {; right } 1-2 \text { (with } \\
\text { additional writing); } \\
\text { bottom: } 0-0.5 \text {; top: } 0.5\end{array}$ & Yes. Latin. \\
\hline $\begin{array}{l}469= \\
\text { Inv. } 5389\end{array}$ & 2443 & Latin & $19 \times 15$ & $\begin{array}{l}\text { Right: } 0.5-1 \text {; bottom: } 1 \text {; } \\
\text { top: } 0.5-1\end{array}$ & Yes. Greek \\
\hline $\begin{array}{l}470= \\
\text { Inv. } 5394\end{array}$ & 2448 & Latin & $18.5 \times 15$ & Right: 1 ; bottom: 0.5 & No \\
\hline $\begin{array}{l}471= \\
\text { Inv. } 5393\end{array}$ & 2447 & Latin & $22.4 \times 17$ & $\begin{array}{l}\text { Left: } 0.5-1 \text {; right: } 0.5-1 \text {; } \\
\text { bottom: } 0.5\end{array}$ & $\begin{array}{l}\text { Yes. Latin. } \\
\text { Very faint }\end{array}$ \\
\hline $\begin{array}{l}476= \\
\text { Inv. } 5397\end{array}$ & 2451 & Greek & $22 \times 24$ & $\begin{array}{l}\text { Left: } 2 \text { (with additional } \\
\text { writing); right } 2 \text {; top } 1 \text {; } \\
\text { bottom: } 1\end{array}$ & Yes. Greek \\
\hline $\begin{array}{l}477= \\
\text { Inv. } 5399\end{array}$ & 2453 & Greek & $27 \times 17.1$ & $\begin{array}{l}\text { Left 1-2; right: } 0.5-1 \text {; } \\
\text { top: } 1\end{array}$ & No \\
\hline $\begin{array}{l}478= \\
\text { Inv. } 5400\end{array}$ & 2454 & Greek & $32.6 \times 17$ & $\begin{array}{l}\text { Left: } 1 \\
\text { (fragments) }\end{array}$ & Traces \\
\hline $\begin{array}{l}479= \\
\text { Inv. } 5396\end{array}$ & 2450 & Greek & $21.4 \times 16.4$ & $\begin{array}{l}\text { Left: } 1.5 \text {; right: } 1-1.5 \text {; } \\
\text { top: } 1\end{array}$ & Yes. Greek \\
\hline $\begin{array}{l}480= \\
\text { Inv. } 5398\end{array}$ & 2452 & Greek & $14 \times 18$ & $\begin{array}{l}\text { Left: } 2 \text {; right: } 0.5-1 \text {; } \\
\text { top: } 1.5\end{array}$ & Traces \\
\hline Inv. 5395 & 2449 & Latin & $\begin{array}{l}\text { Frg.A } \\
9.7 \times 19: 1\end{array}$ & $\begin{array}{l}\text { Left: } 1 \text {; bottom: } 1 \\
\text { (incomplete) }\end{array}$ & None \\
\hline
\end{tabular}

17 For the original publication: H. C. Youtie and J. G. Winter, Papyri and Ostraca from Karanis, Second Series (Michigan Papyri, Vol. VIII) (University of Michigan Studies, Humanistic Series 50; Ann Arbor: University of Michigan Press, 1951), 1674. For the most recent work on the text (which I have generally followed throughout): S. Strassi, L'archivio di Claudius Tiberianus da Karanis (APF 26; Berlin/New York: Walter de Gruyter, 2008). 
To begin with we could note that the papyrus sheets which make up the letters from Claudius Terentianus to his father Claudius Tiberianus vary considerably in both size and shape. In relation to size we have some relatively small sheets (e.g. P. Mich. 469, 470, 480) being less than half the size of the largest sheet of papyrus (e.g. P. Mich. 478) and the rest spread in between. In relation to shape: some are almost square (e.g. P. Mich. 467, 476), some are wider than they are high (e.g. P. Mich. 468, 480), while others are higher than they are wide (e.g. P. Mich. 469, 477, 478).

In relation to the writing itself the papyri have a number of different scribal hands, leading to the widespread view that Terentianus used different secretaries to write down the texts. ${ }^{18}$ A common feature of the writing of the text of the letters is that they consistently fill up almost the entire sheet of papyrus, with generally rather narrow margins (on three occasions wider than normal margins are subsequently used for additional writing, so P. Mich. 467, 468, 476).

An interesting question arising from this is whether Terentianus chose a piece of papyrus which suited the length of the letter which he intended to write, or whether he varied the length of the letter to the size of the papyrus sheet he had to hand at that moment. ${ }^{19}$ Perhaps this way of posing the question is too much of a dichotomy, and what can be affirmed is that there is a relationship between format and content such that every sheet is generally filled with writing (although there is some room for variation in relation to the amount of space left for any closing greeting). The dictation of these letters would appear to have taken reasonably careful account of the space available. ${ }^{20}$

18 In addition to the differences in writing, P. Mich. 468 has two columns of text (admittedly this is the widest sheet of papyrus used in these letters).

19 Terentianus obviously had reasonably good access to supplies of papyrus. In P. Mich. 468 he writes to Tiberianus that he is sending, presumably with the letter, 'two papyrus rolls for school use, ink (for use) on the papyrus, five (?) pens' (lines 1819: chartas sc[holare]s d[u]as et in charta atramentum et calamos $\mathrm{q}[\mathrm{u}] \mathrm{i}[\mathrm{nq}] \mathrm{ue})$, and in P. Mich. 481 in a letter to Tasoucharion, his sister, he refers to having sent her papyrus

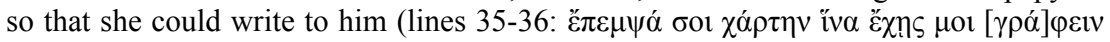

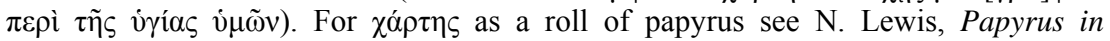
Classical Antiquity (Oxford: Clarendon, 1974), 70-78. (References to sending papyrus in the hope of receiving a reply occur quite often in the documentary letters of antiquity).

20 On the relationship between space and the number and extent of greetings added to the close of the letters, see below, p. 236-38 
Another feature of these letters is that additional messages are sometimes written in a different script, or hand-writing style from the main text. This suggests both the use of a scribe or secretary to write the main script, and then the author taking up the pen for a final personal message. A good example of this is in P. Mich. 479. This letter opens as follows:

Claudius Terentianus to Claudius Tiberianus, father and lord, very many greetings. Before all else I pray for your health and prosperity, which are my wish. I marvel that after you sailed upcountry you did not write to me about your well-being, but until today I have been anxious because you were indisposed when you left me. Please, then, write me a reply at once concerning your well-being. (lines 1-10)

After some other matters the letter closes, and then a different hand has added in the space at the foot of the papyrus sheet: I pray you fare well $(\dot{\varepsilon} \rho \rho \tilde{\omega}[\sigma \theta \alpha] \hat{i} \sigma \varepsilon[\varepsilon \tilde{v}] \chi \sigma \mu[\alpha] \imath) .{ }^{21}$ It would seem quite plausible to attribute this to Terentianus himself, adding a closing greeting in his own hand, adding a personal emphasis to one of the main points of this letter. ${ }^{22}$

Here in a very simple way we have something similar to Paul's apparent practice of adding a personal message or signature to a text primarily written by a secretary. Paul refers to writing in his own hand at the close of a number of letters, highlighting his own taking up of the pen-assuming that the previous material had been written for Paul by a secretary (1 Cor. 16:21; Gal. 6:11; Phlm. 19; Col. 4:18; 2 Thess. $3: 17$ ); the only explicit reference to a secretary occurs in Rom. 16:22: 'I Tertius, who has written this letter in the Lord, greet you'. ${ }^{23}$

21 For this reconstruction Strassi, L'archivio, 59.

22 In P. Mich. 472, a letter from Tiberianus to Longinus Priscus found in the same archive, there is a similar phenomenon in a Latin letter, with a second hand adding a final message, 'I pray for your good health, my Lord' (lines 24-25: opto t[e] domine ben[e v]alere). Another addition which might be attributed to Terentianus occurs on the back of P. Mich. 468 in the form of address. One hand has written: 'Claudius Terentianus to Claudius Tiberianus ... Terentianus' A different hand has added what would seem to be a more personal version of the address: 'Deliver to Claudius Tiberianus, my father (patri), from Claudius Terentianus, his son (filio).'

23 My translation in view of the word order, with the support of Origen and among recent commentators Jewett, Romans, 978f. (although I do not accept all the features of his interesting discussion). For discussion see G. J. Bahr, 'The Subscriptions in the Pauline Letters' JBL 87 (1968): 27-41; R. N. Longenecker, 'Ancient Amanuenses and the Pauline Epistles' in New Dimensions in New Testament Study (eds. R. N. Longenecker and M. C. Tenney; Grand Rapids: Zondervan, 1974), 281-97; E. R. Richards, The Secretary in the Letters of Paul (WUNT; Tübingen: J.C.B. Mohr, 1991); C. Keith "'In My Own Hand": Grapho-Literacy and the Apostle Paul' Biblica 89 (2008): 39-58. 


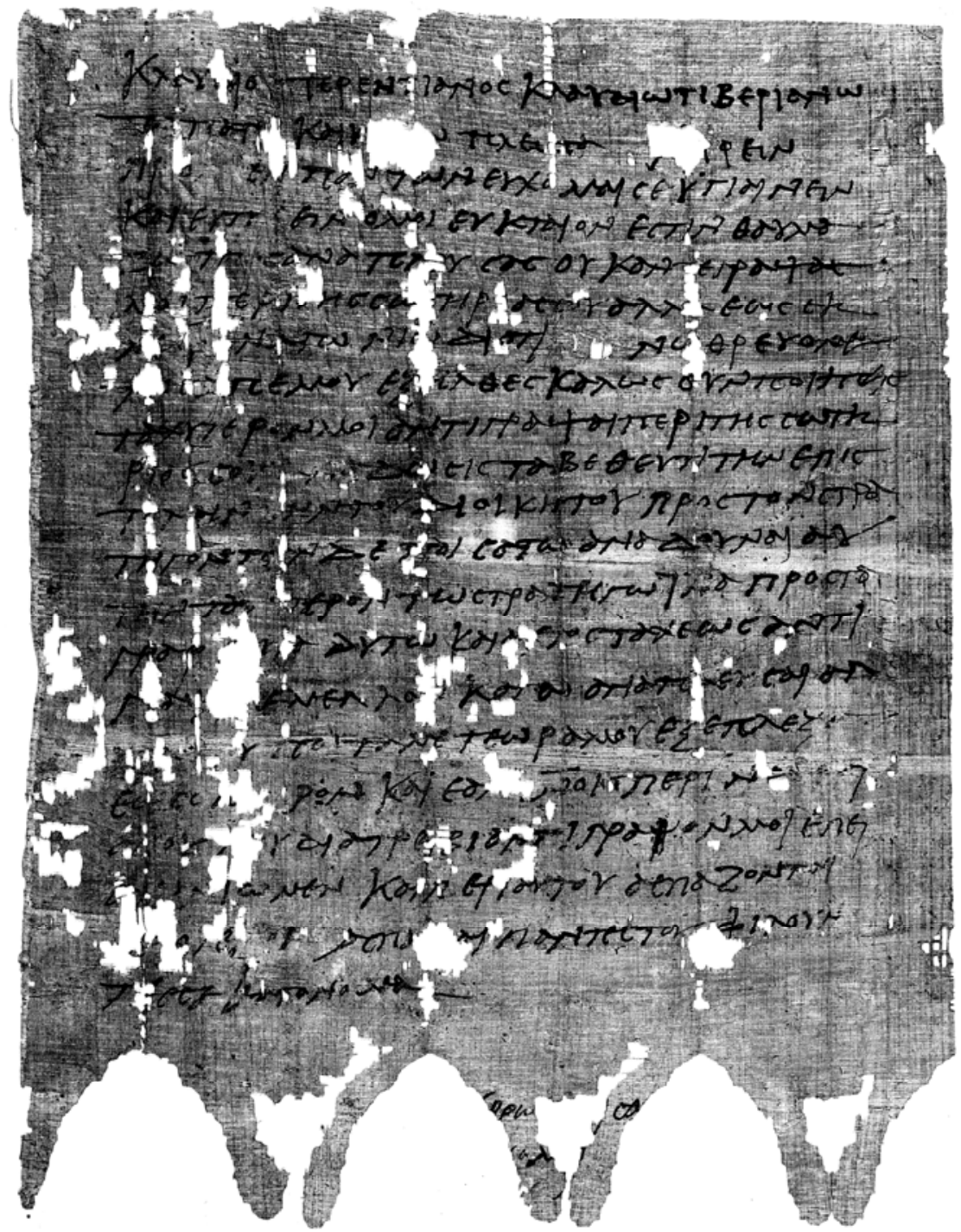

If we turn from the pattern of writing to the pattern of survival we can notice a distinctive pattern of damage to one end of the letters, which suggests that they were stored in the form of a roll (with no other folding). We can observe this pattern in a striking way in P. Mich. 479- three and a half rolls of the papyrus can be seen in the damage at the bottom of the letter (the right hand edge in the following photograph), while the other end has suffered little damage. A similar pattern of damage can be observed in some other letters in this archive (notably P. Mich. 468 and 471). 




While this feature of the preservation of the papyri suggests that the letters were stored as rolls, another feature suggests they were probably sent as rolls. It can be observed on the back of many of the letters that the address instruction extends across the full width of the page. The back of the same letter shown above (P. Mich. 479) shows the extent of the address on the verso quite clearly (even if the text itself is not so clear). Again this can be observed in other letters in the archive (P. Mich. 469, 475, 476). 
From this combination of features, that is storage in roll form and an address line which normally extended across the full width of the page, it seems likely that the letters themselves were sent as rolls, and not folded (as some other letters in antiquity clearly were). ${ }^{24}$ In this they would certainly have been like most of the New Testament letters , which would have been too extensive to have been folded..$^{25}$

The use of an address instruction on the reverse of a letter is a standard feature of surviving documentary letters from antiquity (unfortunately it is also a common feature that the text of the address instruction is often damaged rather than complete and clear). With these letters from Terentianus we can note that nearly all the letters have an address on the reverse, or at least traces are observable (either in available photographs or as presented in published editions). ${ }^{26}$ These address instructions are generally very brief with occasionally some

24 P. J. Parsons, 'Background: The Papyrus Letter' Didactica Classica Gandensia 20 (1980): 3-19, at pp. 4-5; R. Luiselli, 'Greek Letters on Papyrus. First to Eighth Centuries: A Survey', Asiatische Studien 62.3 (2008): 677-737, at pp. 710-11. B. Porten's survey of Aramaic letters suggests folding of various types was the norm in Aramaic Letters from Elephantine, 'Aramaic Letters: A Study in Papyrological Reconstruction' Journal of the American Research Center in Egypt 17 (1980): 39-75.

25 For ancient letters as rolls see Seneca, Epist. 45.13; Cicero uses the term volumen, e.g. Atticus 10.4.1 (for a long letter from Atticus); cf. also Cassius Dio 46.36.4 (although the situation is not generalisable). 'In physical appearance, a letter on papyrus thus bore some resemblance to a book roll, not least in being rolled up in cylindrical form when it was done, rather than being folded like a modern letters'. P. White, Cicero in Letters: Epistolary Relations of the Late Republic (Oxford: OUP, 2010): 64. I have not noticed any evidence for the use of seals on the letters of Claudius Terentianus, cf. in general K. Vandorpe, 'Seals in and on the papyri of Greco-Roman and Byzantine Egypt' in M.-F. Boussac and A. Invernizzi (eds.), Archives et sceaux du monde hellenistique (Athens 1996), 231-91; also K. Vandorpe and B. Van Beek, "Non Signat Aegyptus"? Seals and Stamps in the Multicultural Society of Greco-Roman Egypt', Seals and Sealing Practices in the Near East: Developments in Administration and Magic from Prehistory to the Islamic Period (OLA 219; eds I. Regulski, K. Duistermaat and P. Verkinderen; Leuven: Peeters, 2012), 81-98.

26 The data presented in the table above was made primarily from the photographs available through http://ipap.csad.ox.ac.uk/Michigan.html (photos included with permission). The three texts which lack any evidence of an address on the verso (P. Mich 470, 477 and inv. 5395-this last one is very fragmentary) do not have images of the recto available. Neither of the two major editions notes any evidence of writing on the verso of these papyri (Youtie; Strassi), notes on APIS record the versos of P. Mich. 470 and 477 as blank (http://quod.lib.umich.edu/a/apis/x-2448/1; http://quod.lib.umich.edu/a/apis/x-2453/1). Traces are noted on APIS for P. Mich 467: 'a few scattered and illegible remnants of the address, which was written in two lines are preserved on the verso' (http://quod.lib.umich.edu/a/apis/x-2445/1), and P. Mich. 478: 'illegible remnants of an address are visible on the verso' (http://quod.lib.umich.edu/a/apis/x-2454/1). 
descriptive comment added to the names. In general the Latin letters use a Latin address (P. Mich. 468, 471), and the Greek letters use a Greek address (P. Mich. 475, 476, 479, 481), the only exception to this is P. Mich. 469, a Latin letter with a Greek address. The address is an instruction to the letter carrier, sometimes beginning with an explicit imperative (generally in Greek å㇒ó $\delta$ os). For example, P. Mich. 476 is the most extensive among the Greek letters:

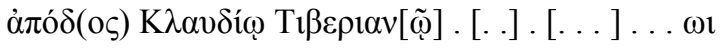

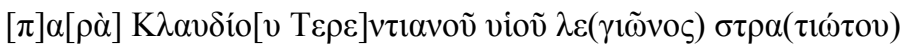

Deliver to Claudius Tiberianus ....

From Claudius Terentianus, his son, a soldier of the legion.

We might fairly plausibly reconstruct the missing portion in the first line from the parallelism of the second line as 'my father' (as is actually used in P. Mich. 468, quoted earlier, and 471) and an additional descriptor, either his position ('speculator', as in P. Mich. 469), or a general statement ('most esteemed', as in P. Mich. 479). Shorter forms of the address may lack the explicit imperative and the additional descriptors. The function of these addresses, reflecting a widespread convention in antiquity, is practical, aiming to ensure delivery to the right person without the need for the courier to open the letter. ${ }^{27}$ Occasionally they become quite extensive, including directions so that the courier can locate the recipient. ${ }^{28}$ Although the address seems primarily intended for the letter carrier, it has another function in shaping the recipient's first impression of the letter. ${ }^{29}$ On the basis of

27 In $1910 \mathrm{~F}$. Ziemann calculated that 205 out of 368 private letters between the Third Century BC and the Fourth/Fifth Century AD had an address on the back of the letter, De epistularum Graecarum formulis sollemnibus quaestiones selectae (Diss phil. Halenses 18; Halle, 1911; also Berlin: Haas, 1912), 277 (so S. R. Llewelyn, 'Prescripts and Addresses in Ancient Letters' New Documents Illustrating Early Christianity 8 (1998): 122-28, 125f).

28 See, for an extreme example, P. Oxy 2719 (III): 'Consignment of Rufus' letters: From the Moon gate walk as if towards the granaries and when you come to the first street turn left behind the thermae, where there is a shrine, and go westwards. Go down the steps and up the others and turn right and after the precinct of the temple on the right side there is a seven-storey house and on top of the gatehouse a statue of Fortune and opposite a basket-weaving shop. Enquire there or from the concierge and you will be informed. And shout yourself; Lusius will answer you ...'

29 For the double function of the address for both letter carrier and recipient see F. Morelli, 'Der Briefschreiber an der Arbeit: Aus der Praxis der Epistolographie' in Stimmen aus dem Wüstensand. Briefkultur im griechisch-römischen Ägypten (eds C. Kreuzsaler, B. Palme and A. Zdiarsky; Nilus 17; Vienna: Phoibos, 2010), 85-91 at p. 91 . 
the address a recipient may decide whether to read the letter straight away or to wait, whether to read the letter privately or in the presence of others. The address creates expectations on the part of the recipient as to what the letter is likely to contain.

In this context it is perhaps worth wondering whether a typical Pauline letter may have had an external address formula which would probably repeat the information in the opening address (with perhaps some complementary additional features): 'deliver to the church in Corinth, from Paul, the apostle of Jesus Christ'. This may not have been necessary with designated letter carriers who would take the letter from Paul to the church as their primary task, but it is interesting to recall the particular way in which the Pauline letter collection has also preserved titles which resemble the type of information the external address would also have carried: 'to the Corinthians'. I don't think that the superscriptions to the Pauline letters in the manuscripts of the Pauline corpus were in fact derived from the external addresses used in each individual letter. More likely they are derived directly from the opening address of the letters. Nevertheless, there is a sense in which they have an analogous function-introducing the letter, creating preliminary hermeneutical expectations, reminding us of the original format of a typical letter. ${ }^{30}$

\section{Health Concerns}

In this and the following sections we will note some of the features of these letters, beginning with the more frequently expressed themes which are also common among the letters of Graeco-Roman antiquity, and discuss their potential relevance to the study of the letters of the New Testament. Perhaps the most frequently mentioned single issue in the letters of Claudius Terentianus is that of health. They include prayers and wishes for good health, and exhibit a general concern with illness. There is, to be sure, a certain degree of conventionality to the opening statements of many of the letters, which open with a prayer for

30 For a survey of studies on the general topic, none of which addresses the superscriptions, see S. E. Porter, 'When and How was the Pauline Canon Compiled? An Assessment of Theories' in The Pauline Canon (ed. S. E. Porter; PaSt 1; Leiden: Brill, 2004), 95-127 or (slightly revised) 'Paul and the Pauline Letter Collection' in Paul and the Second Century (ed. M. F. Bird and J. R. Dodson; LNTS 314; London: Continuum, 2011), 19-36. 
the health of the recipient and (often) a reassurance of the good health of the sender.

'Before all else I pray for your health and success, which are my wish'.

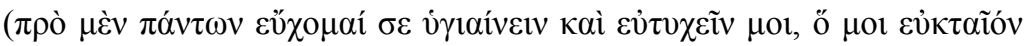
$\dot{\varepsilon} \sigma \tau \imath$, P. Mich. 476:3).

With some flexibility this is the opening of all the Greek letters (477:2-

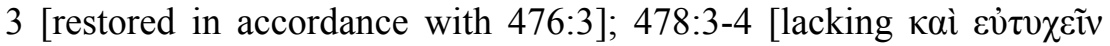
$\mu o 1$, and also restored in accordance with 476:3]; 479:3-4; 480:3

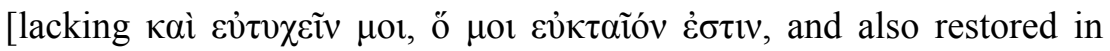
accordance with 476:3]). ${ }^{31}$ The Latin letters are not quite as consistent in always opening with this wish (P. Mich. $467 \& 468$ include a similar passage while 469 does not). ${ }^{32}$

We may note firstly that opening a letter with a prayer for the recipient's health is an exceedingly common practice in ancient letters, indeed a conventional feature of the genre. ${ }^{33}$ Nevertheless, the actual contents of these letters of Claudius Terentianus remind us that conventions are commonly adopted precisely because they are useful for giving expression to the meaningful thoughts of a wide range of people. Given the generally limited life expectancy in the ancient world it is not particularly surprising that the opening general prayer is, on two occasions, followed up with a more extensive discussion of his father's health. ${ }^{34}$ In particular P. Mich. 479, which we have quoted from earlier, opened with 'Before all else I pray for your health and prosperity, which are my wish', and continues as follows:

'I marvel that after you sailed upcountry you did not write to me about your well-being, but until today I have been anxious because you were indisposed

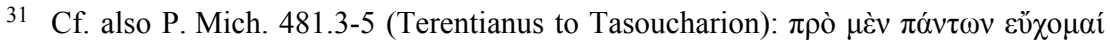

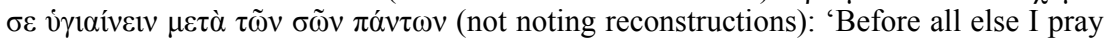
for your health, along with all your family'; P. Mich. 510 (from the same archive:

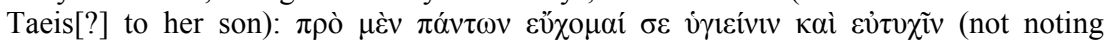
reconstructions): 'Before all else I pray for your health and success'.

32 P. Mich. 467.3-4: 'an[te omn] ia opto te] fortem et h[i]larem [e]t salvom mihi esse cum nostris omn[ibus]': 'Before all else, I pray that you be strong and cheerful and well, together with our entire family'; P. Mich. 468.3-4: 'ante omnia opto te bene [val]ere que m[ihi] [ma]xime vot[a su]nt': 'Before all else, I pray for your health, which is my special wish'.

33 For other examples and discussion see White, Light, 200f; Koskenniemi, Studien, 130-39; Exler, Form, 107-111.

34 W. Scheidel, 'Demography' The Cambridge Economic History of the GrecoRoman World (ed. W. Scheidel, I. Morris and R. Saller; Cambridge: CUP, 2007), 3886, pp. 38-41 for brief review of current thought. 
when you left me. Please, then, write me a reply at once concerning your wellbeing'.

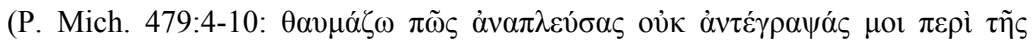

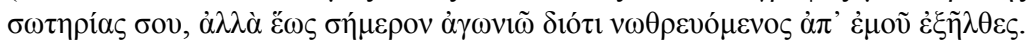

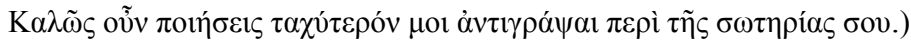

The concern of a son for his father's health may also be reflected in the more expansive than usual closing wish in a second hand (probably that of Terentianus himself): $\dot{\varepsilon} \rho \rho \tilde{\omega} \sigma \theta \alpha i$ $\sigma \varepsilon \varepsilon u ̛ \chi o \mu \alpha 1$, which may be rendered 'I pray for your good health' (P. Mich. 479:23-24). ${ }^{35}$

Something rather similar occurs in P. Mich. 468, which opened with 'Before all else, I pray for your health, which is my special wish'. This letter also includes a further request for news (following the only punctuation space in the whole text): 'Moreover, I ask and beg you, father, to reply to me immediately about your health, that you have recovered your good health (?). I am worried about trouble at home (?) if you do not write back'. (P. Mich. 468:30-35). ${ }^{36}$ This in turn is emphasised with an addition in the right hand margin which explicitly picks up the language of the opening prayer: 'I pray that you enjoy good health for many years with the greatest happiness forever' (P. Mich. 468:64-65). ${ }^{37}$

The letters also contain references to Terentianus being apparently seriously ill, both of which come in the context of the arising communication difficulties. Firstly, in P. Mich. 477 we find, within the general context of urging his father to come to Alexandria to deal with some business matter, Terentianus commenting as follows:

'Since I have found no one to send because I am ill ( $\delta$ iò $\tau$ ò ${ } \omega \omega \theta \rho \varepsilon[v ́ \varepsilon \sigma] \theta \alpha i$ í $\mu \varepsilon$ ), you will therefore do well to conclude your business quickly and sail down to me. For the illness is at this moment no

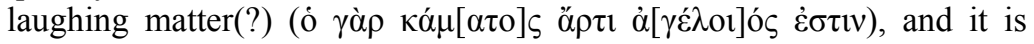

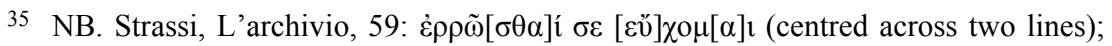
cf. 'I pray that you are well' (White, Light, 176). With this we might compare the

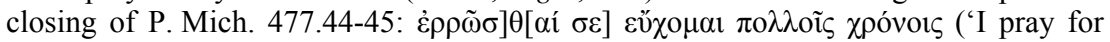
your health through many years').

36 See Strassi, L'archivio, 20 for reconstruction of text as 'et praeterea oro [et] [rogo] te, p[ater, u]t contin[uo mih]i [resc]rib[as de] salutem t[ua]m, te ha[b]ere bo[na] reaccept $[a](\mathrm{m})$. [S]olicitus sum autem de vic $[e]$ in do nese mihi rescribas' (not noting dotted letters).

37 P. Mich. 468.64f: 'bene valere te opto mult[i]s annis felicissime im perpetuo. $\operatorname{Val}(e)$ '. (Strassi, L'archivio, 21). 
even necessary that I be fed by someone else, [as] you will hear when you come to [the city].'

Secondly, in P. Mich. 478 (unfortunately rather fragmentary) we find another reference to an illness. The letter opens with a reference to

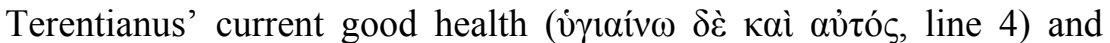
refers back to the time of an illness:

'I want you to know that although [I was ordered] to go out on duty in your absence I was [altogether] unable to go down to Neapolis(?). For it was at that time that ... so violent an attack of illness, and [I was unable] for five days to write to you anything, [not to speak] of going up to you...'

'... I have recovered from ${ }_{39}$ my illness, and I am the more [grateful to you] for coming down ...'

If we pause for a moment to consider NT epistolary matters we note firstly a degree of contrast with this pre-occupation with health and illness. In terms of letter openings, the closest we get to the repeated refrain of Terentianus' letters is in 3 John 2, which is quite distinct within the NT for its closeness to contemporary usage: $\dot{\alpha} \gamma \alpha \pi \eta \tau \dot{\varepsilon}, \pi \varepsilon \rho \grave{i}$

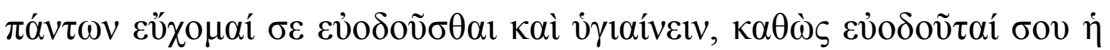
$\psi v \chi \eta \dot{~}{ }^{40}$ The added clause suggests an obvious association between what we might call physical and spiritual 'good health' ${ }^{41}$

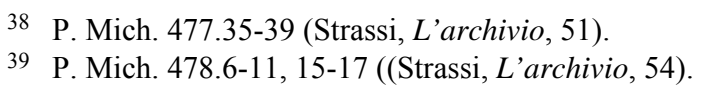

40 'III John gives the best and only clear example of an opening health wish in a NT letter'. R. E. Brown, The Epistles of John (trans. with introduction, notes, and commentary; The Anchor Bible; 1st ed; Garden City, NY: Doubleday, 1982), 790. J. M. Lieu suggests that the general absence of the health wish in the epistolary literature of early Christianity (NT and Apostolic Fathers) is more notable than its presence in 3 John $(1,2$, and 3 John: A Commentary (The New Testament library; Louisville, Ky: Westminster John Knox Press, 2008), 268; cf. The Second and Third Epistles of John: History and Background (SNTW; Edinburgh: T \& T Clark, 1986), 102: 'In a way strikingly unique in the New Testament, the address is followed by a form approximating to the secular conventional health wish' (cf. also pp. 42-44). Against the conjectural reading $\pi \rho$ ò $\pi \alpha ́ v \tau \omega v$ (Piscator acc. NA27; J. Rendel Harris, 'A Study of Letter-Writing', The Expositor Fifth Series, vol. 8 (1898): 161-80, at p. 167; R. W. Funk, 'The Form and Structure of II and III John' JBL 86 (1967): 424-30, at p. 425 note 7) see Lieu, The Second and Third Epistles of John, 44 and H.-J. Klauck, Der Zweite und Dritte Johannesbrief (EKK NT XXIII/2; Zurich: Benziger \& NeukirchenVluyn: Neukircherner, 1992), 80.

41 Cf. Brown, Epistles, 703-704. For an interesting tracing of the Wirkungsgeschichte of 3 John 2 see H. L. Landrus, 'Hearing 3 John 2 in the Voices of History' JPT 11 (2002): 70-88. 
Paul never uses such a prayer for health, preferring to open his letters with a thanksgiving. ${ }^{42}$ Nor do his letters contain frequent complaints or comments about illnesses (although see 1 Cor. 11:30:

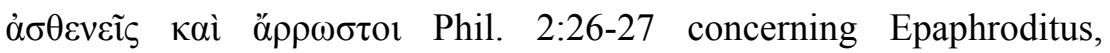

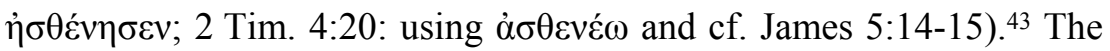
verb vylaiv $\omega$, although it is used elsewhere in the NT of healing from physical illness (so e.g. Luke 5:31; 7:10 [and Matt. 8:13 v.l.]; 15:27) is generally used by Paul in the pastoral epistles for a particular type of healthy or wholesome ('sound') teaching (1 Tim. 1:10; 6:3; 2 Tim. $1: 13 ; 4: 3$; Titus $1: 9,13 ; 2: 1,2) .{ }^{44}$ See also $\sigma \omega \tau \eta \rho i ́ \alpha$, the noun used in the general sense of 'health' $(476: 22 ; 479: 6,9-10$; cf. elsewhere in the same archive: 481:12-13; 510:10), a sense it has only rarely, if anywhere, in the NT, and in fact never in the epistles, where it always refers to eschatological 'salvation'. ${ }^{45}$

\section{Making Connections: the Desire for News and Greetings}

A second and notable feature of these letters, and a theme attested broadly in the documentary papyri, is the evident desire expressed by the author for the contact represented by a letter and the news

42 The Pauline thanksgivings do have some parallels in contemporary epistolary practice (see P. Schubert, Form and Function of the Pauline Thanksgivings [BZNW 20; Berlin: A. Töpelmann, 1939], 158-79; cf. also P. T. O'Brien, 'Introductory Thanksgivings in the Letters of Paul' (Supp. Nov. T. 49; Leiden: Brill, 1977).

43 In Phil. 2:25-20 Paul does demonstrate an understanding of the potential impact of rumours of ill-health on the church in Philippi: Epaphroditus had been severely ill (v. 27), the Philippians had heard that he was ill (v. 26), and Epaphroditus had become anxious at the thought that the Philippians knew that he was ill (v. 26). All of this stands (among other things) behind Paul's decision to send Epaphroditus back to Philippi, carrying the letter to the Philippian church.

44 On this see A. J. Malherbe, 'Medical Imagery in the Pastoral Epistles' Texts and Testaments: Critical Essays on the Bible and Early Christian Fathers (ed. W.E. March; San Antonio, TX: Trinity University Press, 1980), 19-35; reprinted in Paul and the Popular Philosophers (Minneapolis: Fortress, 1989), 121-36.

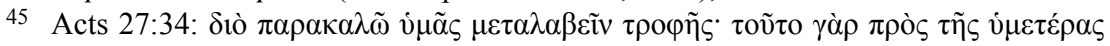

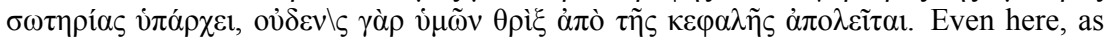
also in Heb. 11.7, the sense is of preservation or deliverance from death BDAG, $985 \mathrm{f}$. (rather than more generally on 'health', as is common in the papyri, cf. LSJ. In Paul's normal (epistolary) usage it generally means 'salvation, w[ith] focus on transcendent aspects', as already found in LXX, BDAG, 986. 
contained in such letters. ${ }^{46}$ This is reflected both in the expression of pleasure at the arrival of a letter: 'I am pleased whenever I have news from you' (P. Mich. 467:4), and more commonly in this collection, and clearly connected with Claudius Terentianus' concern for his father's health, in the anxiety caused by lack of news from home (e.g. P. Mich. 468:31-35 and 479:4-10 [cited above]), hence for example the regular request for replies to the letter: 'I beg you, father, to send me a reply promptly' (P. Mich. 468:41f.), or 'Please write me a reply about your

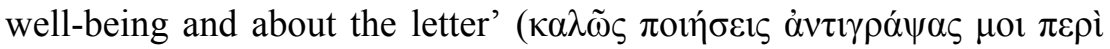

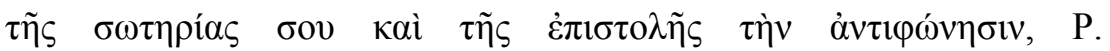
Mich. 476:21-23). ${ }^{47}$

The letters themselves contain snippets of news from a range of acquaintances: "both Kalabel and Deipistus have enlisted in the Augustan fleet' (P. Mich. 467:12-13), 'know that Carpus came here in his wanderings and Dius was found in the legion' (P. Mich. 468:4344); or news is sought, 'if you know about Nemesianus, where he is staying, write to me' (P. Mich. 479:17-19). ${ }^{48}$

A particular expression of the connections between people is the use of greetings in the closing parts of the letters-sometimes marked in the physical layout of the Greek letters by a large space followed by an elongated alpha of $\alpha \sigma \pi \alpha \sigma \alpha 1 .{ }^{49}$ These include both greetings sent to the recipient from those present with the writer as well as greetings (or instructions to convey greetings) to people at the recipient's location. ${ }^{50}$ A particularly extensive set of greetings occurs in P. Mich 468 (which is also the largest sheet of papyrus in the whole collection):

46 For this general theme in other letters we could compare SB 12177 (III): 'I received your letter today which has made us very glad'; P. Oxy 1676 (III): 'I was really happy

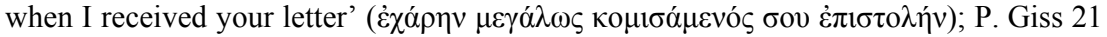
(II); P. Eleph. 13 (III BC); P. Lond 42 (168 BC); P. Lond 434 (II BC); P. Mich. 483 (II); cf. White, 'Introductory Formulae', 95f.; 'Epistolary Formulas', 304.

47 In P. Mich. 481, a letter from Terentianus to Tasoucharion, his sister, he three times urges her to write back to him (lines $8,11 \mathrm{f}, 35 \mathrm{f}$ : here he mentions that he has sent papyrus so that she can write).

48 None of these is mentioned anywhere else in the archive. For another example from the archive of the exchange of news by letter cf. P. Mich. 475 (Papirius Apollinarius to Claudius Tiberianus): 'you wrote me, saying that Gaius had sold something. I therefore ask you, brother, to find out what he has sold, and write to me. And about Sextus, I heard that he passed away. So learn who his heir is and when the will is to be opened.' 49 This is observable in P. Mich. 479.20; cf. 475.19; cf. also P. Oxy 3313.22 (from a similar time).

50 More generally in the documentary papyri cf. Koskenniemi, Des Griechischen Briefes, 148-51; Exler, Form, 69-77; White, 'Epistolary Formulas', 298-99; Mullins, 'Greeting', 418-23; Wiema, Neglected Endings, 39-45. 
My mother and my father and brothers greet you; and know that everything goes very well at home. Greet Aphrodisia and Isityche. Greet Arrius the centurion together with his family, Saturninus the clerk together with his family, Capito the centurion together with his family, Cassius the adjutant together with his family, Tyrannius the adjutant together with his family, Sallustius together with his family, Terentius the pilot, Fronto together with his family, Sempronius Italicus, Publicius, Severinus, your colleague Marcellus, and Lucius. Greet Serenus the clerk together with his family. Greet all our comrades. Farewell. (P. Mich. 468:46-63)

These greetings serve to connect, through the vehicle of the written communication, the family group around the sender with the recipient, and the sender with an extensive network of friends and colleagues (some of whom are greeted in other letters as well). ${ }^{51}$ Although none of the other letters has such an extensive account of greetings, almost all of the letters have some greetings. It could be that the extent of greetings is connected with the amount of space available - P. Mich. 467 includes greetings in the side margin; P. Mich. 469 is on a relatively small sheet of papyrus and includes only 'Greet those who love us' (line 21); three other letters, of various sizes, all close with the general comment: 'Greet all [our] friends, each by name' (o' $\sigma \pi \alpha \sigma \alpha l$

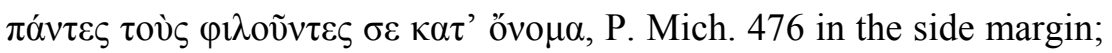
P. Mich. 477:4344 \& 479:20-21). 52

It is interesting to observe within the Pauline letters similar types of greetings, some of which are more extensive (e.g. Rom. 16:3-16 for greetings to individuals and groups in Rome; Col. 4:10-14 for greetings from those present with Paul, cf. also Rom. 16:21-23) and others more abbreviated (e.g. Phlm. 23-24 from mostly the same people as in Colossians but much more compact) and very often both general and abbreviated (1 Cor. 16:20; 2 Cor. 13:13; Phil. 4:21-22-where it would

51 Aphrodisia and Isityche: P. Mich. 468.49 and 467.33; Saturninus: P. Mich. 468.51 and also mentioned in 471.26 (assuming the same person is intended); Terentius: P. Mich. 468.55-56; 467.34; Marcellus: P. Mich. 468.59; 467.34; Serenus: P. Mich. $468.60 ; 467.34$.

52 There is some damage, but P. Mich. 479.20f is clear, while P. Mich. 477.43f reads:

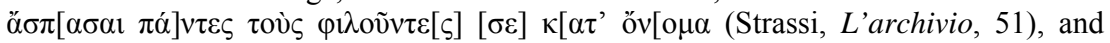

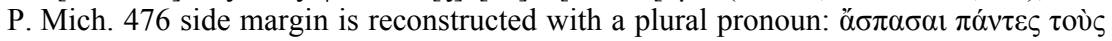

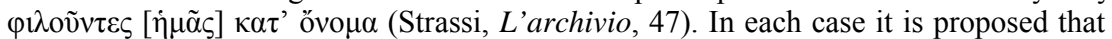

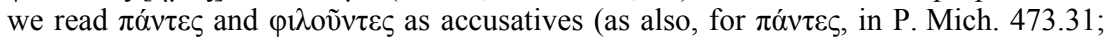
475.18; 476.23). 
not necessarily be appropriate for Paul to single out particular people in the greetings). ${ }^{53}$

In the Pauline letters there are particular reasons for some of the more extensive greeting sections-both Romans and Colossians are addressed to churches which Paul has not personally visited and for whom it is relevant to maximize the personal contacts which do exist. Similarly the greetings in Rom. 16:3-16 are expressed using an unusual plural imperative form - the whole Christian community in Rome is expected to personally embody the welcome which the letter commands in extending greetings to those listed. ${ }^{54}$ Possibly for Paul as well practical issues of available space towards the end of a letter contributed to the amount of detail given in the greetings. ${ }^{55}$ Certainly

$53 \dot{\alpha} \sigma \pi \dot{\alpha} \zeta \mathrm{ov \tau \alpha l} \dot{v} \mu \tilde{\alpha} \varsigma$ oi $\dot{\alpha} \delta \varepsilon \lambda \varphi o \grave{~} \pi \alpha \dot{v} \tau \varepsilon \varsigma$ 'all the brethren greet you', 1 Cor. 16:20;

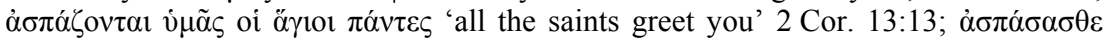

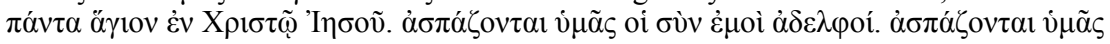

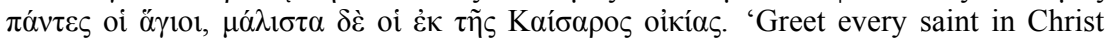
Jesus. The brethren who are with me greet you. All the saints greet you, especially those of Caesar's household', Phil. 4:21-22. Wording that is closest to that of these

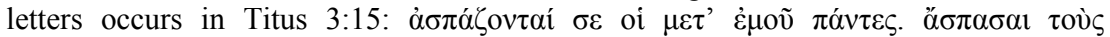

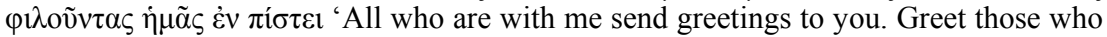

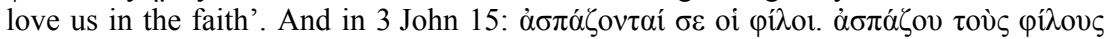
$\kappa \alpha \tau$ ' óvo $\mu \alpha$ 'the friends greet you, greet the friends by name'.

54 Most clearly recognised by F. Watson, Paul, Judaism, and the Gentiles: Beyond the New Perspective. Revised and Expanded Edition (Grand Rapids: Eerdmans, 2007), 186-87 (noting also H. Schlier, Der Römerbrief: Kommentar (HtKNT 6; Freiburg; Basel; Vienna: Herder, 1977), 442-43); cf. also P. Lampe, From Paul to Valentinus: Christians at Rome in the First Two Centuries (ET M. Steinhauser; London: Continuum, 2003), 156-57. I would not take the imperative form as simply 'a surrogate for the first person indicative form' (so H. Gamble, The Textual History of the Letter to the Romans: A Study in Textual and Literary Criticism (S\&D 42; Grand Rapids: Eerdmans, 1977), 93 (and followed by e.g. D. J. Moo, The Epistle to the Romans (NICNT; Grand Rapids: Eerdmans, 1996), 919; J. D. G. Dunn, Romans (2 vols; WBC; Dallas: Word, 1988), 891) - this argument lacks any supporting evidence and involves a non sequitur. The use of the imperative form in Phil. 4:21, in the context of the wider appeal for unity throughout the letter, suggests a parallel expectation - the instruction to greet every saint is 'directed to all and every Philippian Christian' (D. Peterlin, Paul's Letter to the Philippians in Light of Disunity in the Church (NovTSS 79; Leiden: Brill, 1995), 226 - although Peterlin unfortunately does not specifically discuss the imperative form).

55 I take the rather straightforward epistolary parallels to both extensive and contracted greetings in different letters to support the general consensus that the original form of the Corinthian letters had such generalised greeting forms. For a different view D. Trobisch suggested that the abbreviated greetings in 1 Cor. 16:20 and 2 Cor. 13:13 arose as Paul edited the original letters, which on his view 'must have had some kind of personal greetings that are now missing', for 'publication', Paul's Letter Collection: Tracing the Origins (Minneapolis: Augsburg Fortress, 1994), 57-62, where it is clear that he would include Galatians in the same type of redaction (quotation from p. 61). Trobisch argues, on the claimed basis of editorial practices in other ancient 
they are very important to Paul, serving to connect different groups of Christians with each other, and thus 'promoting unity and fellowship among the various churches'. ${ }^{56}$

\section{The Role of the Letter Carrier}

Although the letters are all that remain to us, it is abundantly clear from these letters that in their initial context the letters were accompanied by letter carriers who were also involved in the transportation of a wide variety of goods (mostly between Karanis and Alexandria). Indeed, the availability of a letter carrier was crucial to the epistolary communication. If one is lacking then the letter must wait, ${ }^{57}$ whereas if one is available the letter can be written and delivered. Although it is not always possible to identify the carriers of these epistles, there are frequent references to letter carriers within the letters which concern their role in the transportation of various goods alongside the familial greetings and wishes in the letters. Generally these can be identified as lettercarriers only through the use of various simple formulae ('I have sent by ...' or 'receive through ...') and by discerning the whole situation implied in the letter. Most often they are named, but not in every case.

Practically every letter in the collection mentions the transportation of various goods alongside the familial greetings and wishes in the letters. ${ }^{58}$ This gave rise to a certain complexity of the communication

letter collections, that 'it is very natural for an author to sum up greetings when he prepares his letters for publication' (p. 59). But this claim is based on the composition of several opening salutations in letters of Cyprian (from two centuries after Paul) and some rather general reflections concerning revisions of texts in later editions (with an example from a fourth century literary text-D. Trobisch, Die Entstehung der Paulusbriefsammlung: Studien zu den Anfängen christlicher Publizistik (NTOA 10; Göttingen: Vandenhoeck \& Ruprecht, 1989), 96-97 adds a further fourth century literary example), none of which concerns, let alone suggests, editorial alterations of closing greetings.

56 Wiema, Neglected Endings, 115; see pp. 104-117 for a useful discussion of the greetings in Pauline letters; cf. also T. Y. Mullins, 'Greetings as a New Testament Form' JBL 88 (1968): 418-26.

57 Cf. P. Mich. 476.20-21: 'I wrote you this letter at night, having found an opportunity, but I was not able to send it'; P. Mich. 477.35-37: 'I have found no one to send because I am ill, you will therefore do well to conclude your business quickly and sail down to me.'

58 P. Mich. 469 is concerned with the procurement of various items, including a mattress; P. Mich. 470 discusses money, linen and clothing; P. Mich 477 deals with problems raised by the non-arrival of a promised package (discussed below). 
process and a concern for security, lest the carriers pilfer some of the goods en route. In P. Mich. 476:5-9 Claudius Terentianus begins the body of the letter with reference to three recent arrivals of goods of various sorts from his father:

'... I want you to know, father, that I have received a basket from

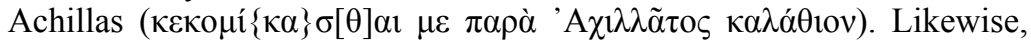
another basket was given to me by the soldier ( $\alpha 2 \lambda \lambda_{0} \kappa \alpha \lambda \dot{\alpha} \theta$ ióv $\mu \mathrm{o}[1]$



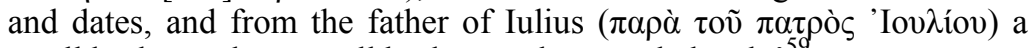
small basket and my small baskets and a sword-sheath. ${ }^{5}$

Claudius Terentianus recommended that all such shipments be accompanied by a letter listing the items which accompany the letter. In a letter acknowledging the safe arrival of some clothes, and replying to the (presumably) accompanying letter which brought news he advises: 'if you are going to send anything, put an address on everything and describe the distinguishing features to me by letter lest any exchange be made en route' (P. Mich. 467:23-25). ${ }^{60} \mathrm{He}$ follows his own advice later in this letter describing the contents and appearance of two amphoras of olives which he is sending home, so that Claudius Tiberianus may identify them upon receipt (presumably with this letter, see lines 27-29). ${ }^{61}$

An interesting account on this topic emerges in P. Mich 477, where Claudius Terentianus replies to an earlier letter as follows:

You write me that you have sent (?) ... through Anubion ( $\gamma \rho \alpha \dot{\alpha} \varphi \varepsilon 1 \varsigma \mu$ or

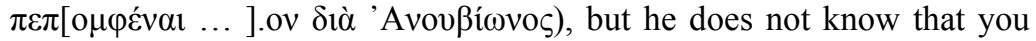
wrote [to me here] and has given me nothing ( From the day that you went upcountry until today, for the first time, I have received the letter and the basket through Aurelius; and do you be concerned, my lord father, to write to Anubion lest he disregard me ... (P. Mich. 477:18-24)

59 Cf. similarly P. Mich. 468.4-8: 'Know, father, that I have received the things that you sent me by ... the veteran and by Numesianus, the ... and the short cloak, and I thank you because you considered me worthy and have made me free from care.'

60 Claudius Terentianus followed the same procedure in a letter to his sister Tasoucharion (P. Mich 481.5-12): 'Receive a basket from the man who delivers the

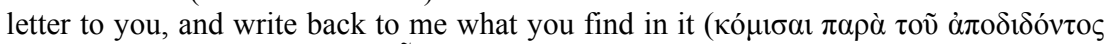

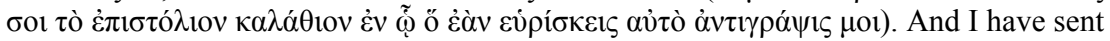
you another basket by Valerius the goldsmith. Please write to me, when you receive it ...'

61 So also in P. Mich 468.8-11: 'I have sent you, father, by Martialis a bag well sewn, in which you have two mantles, two capes, two linen towels, two sacks and (?) a linen covering.' 
It seems clear that Claudius Tiberianus has sent a basket and a letter with Aurelius as letter carrier, and that this letter (or perhaps a previous one) mentioned a second basket (the papyrus is damaged at the crucial point in line 19, but the following passage clarifies the item sent) coming with Anubion. Something had clearly gone wrong with the communication and transportation of the basket, since Anubion denied all knowledge of it. In any case, the situation is clarified later in the same letter:

I want you to know that after the above had already been written to you the basket was brought to me ... by Anubion's father (?), and now at last I have it. (P. Mich. 477:32-35)

Clearly some alternative method of delivery had been organised! This clarification also raises the possibility that an internal change of tone within a letter-in this case from some frustration and concern about the failure of Anubion to deliver the basket to satisfaction in its safe arrival — can be due to the arrival of further information. ${ }^{62}$

In addition to ensuring the safe delivery of the letter and the accompanying goods, the letter carrier can also bring additional oral information for the recipient. As for example in the following :

I want you to know, father, that I have received a basket from Achillas. Likewise, another basket was given to me by the soldier, in which I found two large loaves of bread and dates, and from the father of Iulius a small basket and my small baskets and a sword-sheath. He sent me word

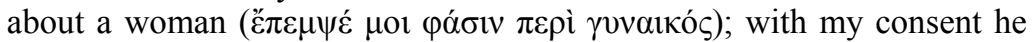

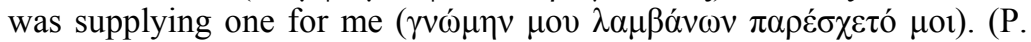
Mich. 476:5-10)

It would, of course, be interesting to know more about this woman, but further information is lacking in the letters-it seems to have been a matter primarily conducted through oral messages.

The letter carrier has a particularly important role in relation to letters of recommendation - the one who is recommended is the one who conveys the letter from the sender to the recipient. Quite a large number of letters of recommendation are attested among the

62 Another example in the archive is in a letter from Claudius Tiberianus to Longinus Priscus (which incidentally does specify the letter carrier): 'As I was about to send to you the letter that Sempronius Clemens, the frumentarius, will deliver to you, I found at his place, by dint of thought and good luck, also the two letters that you want, and I sent them to you under seal.' (P. Mich. 472.14-20). 
documentary letters on papyrus. ${ }^{63}$ Indeed there is an interesting letter of recommendation for one Terentianus, dated to $\mathrm{AD} 136$, which may well refer to Claudius Terentianus on the occasion of his discharge from the legion: 'Now then I ask you, receive with my recommendation the discharged soldier Terentianus who brings you this letter ... ${ }^{64}$ As is customary, the one who is recommended carries the letter of recommendation from the sender to the receiver, the letter itself then serves as the means of introduction. ${ }^{65}$ Neither surviving examples nor the ideal types of the handbooks provide much guidance as to the use of such letters, but in one of the letters of Claudius Terentianus to Claudius Tiberianus he mentions such letters in the context of his desire to be transferred (from the Augustan fleet based in Alexandria) to a cohort (in the Roman army):

... And if god should be willing, I hope to live frugally and to be transferred to a cohort; but here nothing will be accomplished without money, and letters of recommendation have no value unless a man helps himself (epistulae commandaticiae nihil valunt nesi si qui sibi aiutaveret). I beg you, father, to send me a reply promptly. (P. Mich. $468: 35-42)^{66}$

This note supports the view that letters of recommendation were designed to introduce one person to another in order to effect personal communication between the two, but they leave some of the initiative with the one recommended (hence the rather studied vagueness of most letters of recommendation-leaving the issues to be clarified in conversation): 'letters of recommendation have no value unless a man helps himself' ${ }^{67}$

63 C.-H. Kim, Form and Structure of the Familiar Greek Letter of Recommendation (SBLDS 4; Missoula (Mt): SBL, 1972) provides texts for 81 letters of recommendation from the papyri.

64 P. Cornell inv. I. 64; N. Lewis, 'A Veteran in Quest of a Home' TAPhA 90 (1959): 139-46; Strassi, 69-71.

65 Rhetorical handbooks provided guidance on the normal form of the letter of recommendation. Pseudo-Demetrius, Epistolary Types 2 offers an example of the commendatory type ( $\dot{o} \sigma v \sigma \tau \alpha \tau \iota \kappa o ́ s)$ : 'So-and-so, who is conveying this letter to you, has been tested by us and is loved on account of his trustworthiness...' (A. J. Malherbe, Ancient Epistolary Theorists SBLSBS, 19; Atlanta, GA: Scholars Press, 1988), 32-33.

66 Assuming that 'aiutaveret' is a misspelling for 'adiutaverit' (Strassi, L'archivio, 22; cf. Adams and original editors).

67 Cf. also P. Mich. 498 (II): 'very many thanks to you, brother, because of having been concerned about me; your recommendation helped me a great deal'. (White, Light from Ancient Letters, 115A). 
These roles for letter carriers - transporting goods, bringing oral messages, bearing letters of recommendation - can be observed more generally in the epistolary literature of antiquity and the papyri in particular. ${ }^{68}$ In addition, they can also be observed within the epistolary communication of early Christianity. Letters of recommendation were used in early Christianity and knowledge of their function is assumed within the New Testament (see Acts 18:27; cf. 9:2; 22:5; cf. also 2 Cor. $3: 1-3)$. There are also echoes of the recommendation terminology at those points where Paul introduces his letter carriers (most clearly in Rom 16:1-2, but also to some extent at 1 Cor 16:15-18; Phil 2:25-30), an introduction which we may presume was intended to initiate a personal relationship between the letter carrier and the recipients of the letter. This is clearly the case for the letter which emerged from the council of Jerusalem (Acts 15:23-29). This letter not only explicitly identifies those who carried the letter, but also, on the basis of content and context, explicitly states that the role of the letter carriers is to affirm orally the message of the letter-they 'themselves will tell you

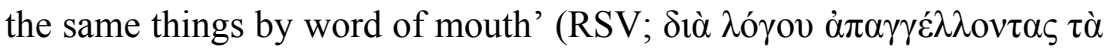

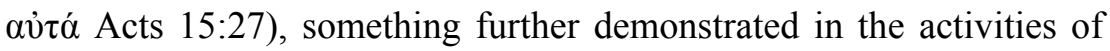
the named letter carriers in the account of the reception of the letterwhere Judas and Silas 'encouraged the brethren with many words' (15:32), while Paul and Barnabas teach and preach in Antioch (15:35).

For the Pauline letters, named letter carriers can be identified —on the basis of epistolary conventions, recommendatory language, and traditional identifications - for at least seven of the Pauline letters: Phoebe (Rom. 16:1-2); Stephanus (with Fortunatus and Achaicus) (1 Cor. 16:15-18); Titus (2 Cor. 8:16-24); Tychicus (Eph. 6:21-22); Tychicus (with Onesimus) (Col. 4:7-9); Epaphroditus (Phil. 2:25-30); Onesimus (Philemon 10-12). It is probably assumed (both by Paul and the recipients) that the letter carrier of a Pauline letter would bring oral messages and greetings in addition to the letter itself (the 'normal' placement of the introduction of the letter carrier immediately before the greetings also suggests this). In addition, on a couple of occasions this is made quite explicit (Col. 4:7-9; Eph. 6:21-22). ${ }^{69}$

68 See P. M. Head, 'Named Letter-Carriers among the Oxyrhynchus Papyri' JSNT 31 (2009): 279-99.

69 For a discussion of the role of Tychicus in Colossians see P. M. Head, 'Tychicus and the Colossian Christians: A Reconsideration of the text of Colossians 4.8' Texts 
Among the Pauline letter carriers there are no explicit indications that they are also carrying goods along with the letters, although doubtless Epaphroditus had carried some gifts in the form of support to Paul from the Philippian church, presumably money (Phil. 2:25; 4:18). Paul does propose that the collection for the poor in Jerusalem should be accompanied by representatives of the Gentile churches attested with letters (1 Cor. 16:3). ${ }^{70}$

\section{Conclusion}

Although there is no particular connection between this collection of letters and those letters arising from early Christianity collected within the New Testament, the study of these letters, and particularly their statements and assumptions concerning epistolary communication have generated a number of helpful issues and questions for the study of New Testament letters, both in terms of similarities and differences. In format the New Testament letters were more than likely also sent in roll format, although for the most part they are far more extensive than the normal documentary letter of antiquity. Recipients of an extensive Pauline letter may well have experienced a degree of generic confusion - the presence of a letter carrier alongside the generic framing material (address, thanksgivings, greetings etc.) are reasonably straightforward, but the vast bulk of material - experienced initially as a very large roll and subsequently as an extensive textual argument, together with the collective form of address, would not have fitted 'normal' epistolary expectations.

Some themes and features within NT letters are adopted from normal epistolary behaviour-for example, greetings which connect communities in different places through the written text and accompanying letter carrier. Indeed given the relatively common Pauline practice of introducing the letter carrier immediately before the greetings (Rom. 16:1-2; 1 Cor. 16:15-18; Col. 4:7-9) it may have been assumed that the named letter carrier in such circumstances could have facilitated the greetings with additional personal messages. In any case

and Traditions: Essays in Honour of J. Keith Elliott (ed. J. Kloha and P. Doble; NTTSD 47; Leiden: Brill, 2014), 303-315.

70 On the need for practical security in this matter see D. E. Watson, Paul's Collection in Light of Motivations and Mechanisms for Aid to the Poor in the FirstCentury World (Durham University, PhD Thesis, 2006), 166-69. 
the whole question of the role and function of epistolary greetings, which would seem to have attracted much less attention within New Testament studies than the opening thanksgivings, could do with a thorough treatment. ${ }^{71}$

Other themes and features of normal epistolary practice are either absent or shifted in a radical new direction within the New Testament - the concern for the health of the recipients is, from one perspective entirely absent from the Pauline letters, although from a different perspective it is transformed into a universally assumed concern for the health of his churches. The named letter carriers would appear to have been charged with this same concern for the health and growth of the recipients, although this is affirmed only in the case of Titus-'Did Titus take advantage of you? Did we not act in the same spirit? Did we not take the same steps?' (2 Cor. 12:18; cf. 7:5-16); and Tychicus_-'he will encourage your hearts' (Col. 4:8; Eph. 6:22).

71 The whole topic of the typical format of ancient letters and the initial format of the New Testament letters could also do with a properly thorough analysis. 